\title{
Insufficient data, short time spans, illusions and multiple pressures: designing the German Monetary Union in $1990^{1}$
}

\author{
Wolfgang Zank ${ }^{2}$
}

\begin{abstract}
The German unification in 1990 generated many benefits, but also many disappointments. After the introduction of the monetary union between the GDR and West Germany on 1 July 1990, the East German industry collapsed, and mass unemployment became persistent. Ever since the modalities of the monetary union have been discussed controversially.

This paper reconstructs the decision-making processes and negotiations towards monetary union. To a high extent, this reconstruction is based on original documents. Early on in Bonn a consensus was reached that monetary union had to be introduced soon, the rapid decline of the GDR making stepwise approaches impossible. Many officials were aware of the detrimental effects of a 1:1 conversion of the wages. But few dared to go against the widespread demands for 1:1 in the GDR population and government, not the least because of over-optimistic promises before the elections in the GDR in March 1990.
\end{abstract}

Keywords: decision-making processes, GDR economy, German monetary and economic union, German reunification, transition to market economy

JEL codes: K0, K2, K3, O1, P1, P2, P3, P5, F0, F2, F4, F5.

\section{Introduction}

The process of German reunification happened with remarkable speed: On 9 November 1989 the Berlin Wall fell and on 3 October 1990 the five new Bundesländer of Eastern Germany became part of the Federal Republic of Germany. A decisive step here was the creation of a monetary and economic union between the two German states which was essentially an extension of the Western Deutschmark and West German economic legislation to the German Democratic Republic.

\footnotetext{
${ }^{1}$ Article received 27 December 2018, accepted 1 February 2019.

2 The Faculty of Social Sciences, Department of Culture and Global Studies, Aalborg University, Kroghstræde 3, 9220 Aalborg, Denmark,wzank@cgs.aau.dk.
} 
28 years later the balance is somewhat mixed. On one hand, many indicators point to a process of conversion between East and West Germany. For instance in East Germany in 1991 the Gross Domestic Product per inhabitant was 43 percent of the Western German level; by 2016 it had risen to 73 percent (Jahresbericht, 2018, p. 2) By 2017, unemployment was 5.3 percent in the West and 7.6 in the East, the lowest level since 1994 (Jahresbericht, 2018, p. 106).

Other indicators highlight persistent weaknesses. Hardly any big company is headquartered in the East. Many companies are owned by West-German or foreign concerns. Lower levels of Research and Development investment or lower degrees of internationalization are the consequence (Jahresbericht, 2018, p. 10). Migration between East and West became somewhat balanced in recent years-after decades of substantial East-West flows. On average people are older in the East and this will become more accentuated in the years to come (Jahresbericht, 2018, p. 11).

Thus conversion has been very slow and is still incomplete. Furthermore it has been accompanied by huge transfers from West to East. (This tends to contradict somewhat the last sentence of the previous paragraph.) The arrival of high unemployment and the widespread insecurity created many anxieties and frustrations which became the foundations for xenophobic and right-wing extremist views substantially above West German levels. For instance at the national elections in 2017 the right-wing party Alternative für Deutschland received 12.4 percent at the national average; in the five East German Länder, the figures were between 16.9 percent (Sachsen-Anhalt) and 25.4 percent (Saxonia). Small wonder that there have been intense discussions as to whether perhaps mistakes were made during reunification. In particular the monetary and economic union of 1 July 1990 has been at the centre of much discussion. (For older critical contributions, see Priewe, 1994; Hickel \& Priewe, 1981.) Ulrich Busch and Jörg Roesler published critical assessments more recently, in 2010. Interestingly, the decision to proceed with monetary union (and privatization) rather fast, seems to have been at the center of of much criticism. This question will be dealt with below. On the other hand, the essential problem why the wages were converted at a rate of 1:1 seems to have attracted much less crititical attention.

This paper explores how and why the decisions on monetary union were taken. In the first place, the text contains a historical reconstruction of the negotiations, deliberations and decisions. Under inspiration of Clifford Geertz, Bent Flybjerg and others, much of the text is a "thick description" of what has been going on. This forms the-in the author's view indispensable-basis for more abstract and theoretical reasoning. To these pertain: Who were making the decisions? Who were influentential as advisors? Which were the major problems which the influential actors (deciders and advisors) saw? Which options did they perceive as being workable? Under which constraints did they operate? And finally, which external factors did they have to consider? At times, seemingly technical details were of considerable importance. 
The "thick description" is based on original internal documents, whenever this was possible. These are referenced in footnotes. Usually the federal archives only become available after 30 years. As regards German reunification however, the federal archives have published a special edition of some 430 documents of the Federal Chancellery (Bundeskanzleramt).

Hanns Jürgen Küsters, the chairman of the editing team, has added an introduction to the decision-making processes which is based on the published internal documents but also on many other sources, among them numerous unpublished documents and pieces of literature (Küsters, 1998). Furthermore numerous leading political actors have published accounts of their experiences, either seemingly written by themselves, or written by journalists after lengthy interviews. These types of accounts include, for instance, Federal Chancellor Helmut Kohl (Diekmann \& Reuth, 1996), Minister of the Interior Wolfgang Schäuble, responsible for the negotiations of the two "state treaties" with the GDR (Schäuble, 1993) or Hans Tietmeyer, leader of Bonn's negotiating team as regards the economic and monetary union (Tietmeyer, 1994). Some of these accounts also contain original documents, or at least large parts of them.

The following text is organized chronologically. Section 1 describes the situation in summer and early autumn 1989. The second section then focuses on the fall of the Wall and the demise of the SED dictatorship. At the end of November Chancellor Kohl took the initiative with a Ten-Point Programme, thereby launching a process which was expressly intended to lead to German reunification (Section 3). As explained in Section 4 discussions on a monetary union, as a first step to unification, began in the media and in particular in the ministry of finance in Bonn already in January. Within a rather short space of time the government in Bonn took the idea on board (Section 5). On 7 February the Federal Cabinet officially endorsed the project (Section 6). By then there was already a consensus to introduce the Deutschmark in the GDR fairly soon; a more gradual process was seen as impossible. Finance Minister Theo Waigel presented a revised budget but it was based on highly illusionist assumptions (section 7). Section 8 presents the warnings of an academic advisory expert committee. Section 9 deals with deliberations between Bonn and East Berlin at the expert level. Section 10 outlines the specific political climate of the first free elections in the GDR on 18 March 1990.

Section 11 presents and assesses the Zentralbankrat of the Bundesbank resolution which had a substantial impact on the modalities of the coming monetary union. Section 12 outlines the final negotiations. The introduction of the Deutschmark on 1 July and its very mixed results-the uncompetitive GDR industry collapsed almost completely-is explained in section 13. Finally in the concluding remarks the factors which shaped the modalities of the monetary union are analysed. 


\section{German reunification enters the agenda}

By summer 1989 the West German government was organized along the following lines (Küsters, 1998, pp. 21-32): The Federal Chancellor, Helmut Kohl, decided the political guidelines, the Richtlinien der Politik. He was assisted by the Chancellery, the Bundeskanzleramt, an institution with a wide network. Hanns Jürgen Küsters called it a decision-making centre, but this term is not really correct. The Chancellery and its head, Minister Rolf Seiters, were not in a position to issue instructions, they could only listen, inform and advise. The decision maker was Helmut Kohl.

But Kohl could not decide without restrictions. Already the constitution contained numerous restrictions and all strategic decisions had to be endorsed by the Koalitionsrunde, meetings of the leaders of the government parties and their parliamentary groups. Three parties formed the government, the CDU, the Christian Democratic Union (led by Kohl himself), the Christian Social Union (the Bavarian Christian Democratic party under Theo Waigel), and the liberal FDP, Freie Demokratische Partei (Otto Count Lambsdorff). Legislative acts and treaties, such as the one on monetary union with the GDR, had to be ratified by parliament.

Kohl deemed it very important to work in close contact with important persons, not least foreign leaders. He spent much time in direct talks, face to face or by telephone, in particular with US President George W. Bush, French President François Mitterrand or Mikhail S. Gorbachev in the Soviet Union. He had, however, profound differences with Prime Minister Margaret Thatcher in London, Thatcher was thinking in rather traditional terms of national power whereas Kohl was much more aware of international interdependencies which demanded new political solutions, such as progressing with the European Union. Also the staff in the chancellery were in close contact with their counterparts in Washington, Paris and Moscow.

In 1989 important changes were underway in central and eastern Europe. In the Soviet Union, Gorbachev seemed set to continue his policy of Perestroika (Küsters, p. 33). In Poland in June the Solidarity movement gained an overwhelming victory in the first (almost) free elections. Hungary had also embarked on a course of political and economic reform.

The Soviet Union loosened its grip on the Central and Eastern European countries. The potential implications for Germany were discussed in the American administration in spring 1989. Robert Zoellick wrote on 17 May 1989 that the German question was returning to the agenda, and Gorbatchov might take it up. Foreign Minister James Baker advocated a cautious normalization of the German-German relationship, not unification, and a stronger US-European cooperation where the Federal Republic would be a "partner in leadership" (Küsters, 1998, p. 35). The Federal Republic indeed did not just follow US leadership, but developed important initiatives on its own. 
On 25 August there was a secret meeting at Gymnich Castle near Bonn between the Hungarian Prime Minister Miklós Németh, Foreign Minister Gyula Horn and their German counterparts Kohl and Hans-Dietrich Genscher (and one interpreter). As the German side knew Hungary was considering opening her borders because the government wanted to adhere to the UN refugee convention (Küsters, 1998, p. 43). Hungary's financial problems were also discussed. Németh asked whether perhaps German companies could buy Hungarian assets. Kohl declared he would ask Alfred Herrhausen, Deutsche Bank, and Wolfgang Röller, President of the German Banking Association to discuss these matters. ${ }^{3}$ In cases of particular national interest the German government could accept a Hermes Bürgschaft and then the banks could offer cheap loans because they would be guaranteed by the government. On 11 September, shortly before the party congress of Kohl's Christian Democrats, Németh announced the opening of the Hungarian border; East German tourists could from now on travel freely through Hungary to Austria. Kohl thanked him warmly at the CDU party congress for his "magnanimous act of humanity" (Küsters, 1998, pp. 44f).

From this day onwards the Berlin Wall had a hole. The erosion of the GDR continued, symbolized by the formation of the opposition group Neues Forum, for example. Emigration figures continued to rise not the least because East Germans continued to enter West German embassies in neighbouring countries. Still few, if any, could imagine the dramatic changes ahead.

\section{The fall of the Berlin Wall and the demise of the SED dictatorship}

In September, starting in Leipzig, the first open demonstrations began. When the security forces tried to repress them they provoked more solidarity, not fear. The decisive day was 9 October. "Monday demonstrations" had become a kind of tradition in Leipzig. This time the regime mobilized some 8,000 troops, rumours about a "Chinese solution" circulated. Nevertheless more people than ever, about 70.000, joined the demonstration. Nothing happened-the regime had "retreated across the Rubicon" (Rödder, 2009, pp. 84-89, esp. p. 88).

On 18 October the Central Committee of the Sozialistische Einheitspartei Deutschlands (SED), replaced Erich Honecker with Egon Krenz. The new Secretary General asked experts to produce an "unvarnished" report about the GDR economy. Krenz could read that for decades the GDR had consumed more than it produced. The resulting debt was 2 billion Deutschmarks in 1970 and 49 billion by 1989 . Currently only 35 percent of the expenses in foreign

\footnotetext{
${ }^{3}$ Nr. 28, Vermerk des Bundesministers Genscher über das Gespräch des Bundeskanzlers Kohl mit Ministerpräsident Németh und Außenminister Horn. Schloß Gymnich, 25. August 1989, Dokumente, pp. 377-380, esp. p. 379.
} 
currencies were covered by earnings. Preventing a further rise of foreign debt in 1990 would require lowering living standards by $25-30$ percent. In short the GDR was bankrupt and unable to remedy the situation on its own. This was an important background factor explaining why the coming political transition happened peacefully (Zank, 1997, p. 263).

Support for the reform processes in eastern and central Europe had been an important part of Bonn's policy, not the least in respect of Poland and Hungary. As regards Poland Kohl also hoped for a proper reconciliation as with France. Together with a delegation of 80 high-ranking persons from politics and business the Chancellor arrived in Warsaw on 9 November. After a first meeting with Prime Minister Mazowiecki, Kohl met Lech Wałęsa, the leader of Solidarity movement. Wałęsa expressed his concerns about "uncontrollable developments" in the GDR. He doubted that the Berlin Wall would still be standing in one or two weeks. ${ }^{4}$ Kohl regarded the economic situation in the GDR as a "minor problem". One could activate the GDR economy rather fast. ${ }^{5}$ Kohl was not the only one to have very optimistic views on this subject.

The same day the SED leadership, after some internal chaos, ordered the opening of the Berlin Wall. East Germans could now personally inspect the West. It was not quite the picture of misery painted by SED propaganda. This was perhaps the final blow to the stability of the GDR. However the widespread joy soon became interwoven with new concerns because many GDR citizens went to the West, not only to have a look but also to stay. This stream of Übersiedler weakened the prospects of the GDR economy further and created problems in West Germany which was under a heavy immigration pressure beforehand, e.g. by asylum seekers, family members of "guest workers", or Aussiedler, ethnic Germans from Poland or the Soviet Union. There was already a heavy competition for cheap flats for instance. The East German Übersiedler also experienced xenophobic reactions such as slashing the tyres of their cars (Zank, 1998, pp. 224f). Up to eighty percent of the West Germans said that they regarded the influx more and more as a burden. CDU officials dreaded that the national question would degenerate into a social one (Schäuble, 1993, p. 22).

\section{Kohl's Ten-Point-Programme}

After the fall of the Wall the Bonn government at first concentrated on pragmatic questions. This had the advantage of not unduly alarming Germany's neighbours, but it meant also that the government might appear more like

\footnotetext{
${ }^{4}$ Nr. 76, Gespräch des Bundeskanzlers Kohl mit dem Vorsitzenden der Gewerkschaft “Solidarität", Wałęsa, Warschau, 9. November 1989, Dokumente... pp. 492-496, esp. p. 494.

${ }^{5}$ Ibid., p. 495.
} 
a spectator than an actor. After two weeks Kohl decided to take the initiative and claim leadership. Together with a small circle of advisors he prepared a programmatic declaration. During preparation, as usual, secrecy was observed and no foreign government was informed beforehand, except President Bush (one hour before).

On 28 November Kohl presented his 10-point declaration in the Bundestag successfully surprising everyone. The first points sketched the German-German developments: Urgent short-term measures; economic, technological and cultural cooperation; large-scale West German assistance, made conditional upon profound changes of the political and economic system; then a "contract community" between West and East Germany; and finally "confederate structures" with the aim of creating a federation. The next points dealt with the international aspects: further development of East-West relations; continuation of European integration and its extension to the central and eastern European states; further development of the OSCE process; steps towards armament control, thereby finally reaching a stage of peace where Germany can regain its unity (Rödder, 2009, p. 140f).

Reactions in Germany were mainly positive. Not so abroad. The idea of German unification could still provoke extreme mistrust. In addition questions "pertaining to Germany as a whole" were still in the competence of the four Allied Powers which drew up the Potsdam Agreement in 1945. But Kohl had proceeded with almost demonstrative unilateralism. During the following weeks various governments, notably the Soviet and the American, admonished Bonn to refrain from anything which could destabilize the situation. With some right Kohl could argue that Bonn did nothing to undermine the GDR. It was the rapid decay of the GDR regime which was the destabilizing factor.

\section{The first discussions in Bonn about a monetary union}

In mid-December 1989 Kohl discussed the deteriorating economic situation of the GDR with some advisors. Wolfgang Schäuble, Minister of the Interior, proposed to offer a monetary and economic union to the GDR. According to his account it was only in this way the stream of Übersiedler could be brought under control. If events were to be placed on orderly rails (geordnete Bahnen), then "quick, big steps" had to be taken. The days of power of the SED (renamed PDS in the meantime) were numbered. Schäuble's proposal was received with substantial reservation. Most of the participants judged that the time for such an initiative had not yet come (Schäuble, 1993, p. 21). But soon the idea gained considerable traction. Schäuble's proposal reflected perhaps some ongoing discussions in the ministerial bureaucracy. At least, on 21 December, Thilo Sarrazin, a high official in the ministry of finance, presented a paper on the 
subject. ${ }^{6}$ According to the paper the opening of the border had made it impossible to manage the GDR economy. Qualified labour was draining away, while at the same time demand was rising because of the earnings of commuters or transfers from Übersiedlern as an example. Trust in the GDR Mark was eroding. If the Deutschmark became a parallel currency the effects on the quantity of money would be substantial. This would exacerbate the problem of the insufficient supply of daily commodities. Consequently there was no realistic perspective for a slow, gradual transition to a market economy. Two solutions were possible: Administrative "protective fences, i.e. new barriers at the borders, or the acceleration of the reform process which had to end in an economic and monetary union as early as possible" (Sarrazin, 1994, p. 174).

Shortly afterwards officials in the Ministry of Finance were working on a paper to design concrete steps towards a monetary union. In analogy to Kohl's programme of November 1989, it was called "Ten Points on the Way towards a German-German Currency Union” (Sarrazin, 1994, pp. 176-180). The text envisaged a rather long-term process (as did Kohl's programme). Prices should be liberated, subsidies abolished and the monopolistic Kombinate (industrial conglomerates) dismantled. The whole complex of taxes and levies had to be re-designed: Clear separation of private and state production, lifting corporate finances out of the state budget and introduction of "reasonable" taxation. These two points alone represented quite gigantic (and time-consuming) tasks. In addition foreign trade should be liberalized. Thereafter a fixed exchange rate between the Western Deutschmark and the GDR Mark could be established. A capital market had to be created, e.g. in order to attract foreign capital. "At the end of this process there could be a German-German monetary union with a common currency and common institutions" (Sarrazin, 1994, p. 180).

At around this time the idea of a currency union gained support. Karl-Otto Pöhl, president of the Bundesbank, cautiously endorsed the idea of making the GDR Mark convertible and stepwise anchoring it and on 19 January the SPD politician Ingrid Mathäus-Maier published an article proposing a transition to a currency union: The "currency union with the GDR", she wrote, "would be for the citizens a transparent and convincing signal for quick economic improvement, which could induce them to stay" (Sarrazin, 1994, p. 181).

Presumably and mainly under the impression of the rapidly dissolving authority of the GDR institutions the philosophy in the Ministry of Finance changed: A gradual and long-term transition appeared increasingly unrealistic. Instead the introduction of a market economy and currency union should be simultaneously introduced on a fixed day. On 26 January State Secretary Köhler asked Sarrazin to write these ideas down; the result was delivered three days later (long extracts of the paper: Sarrazin, 1994, pp. 182-190). All accounts in GDR

\footnotetext{
${ }^{6}$ The paper is summarized in some detail, with longer direct quotes, in (Sarrazin, 1994, pp. 174-180).
} 
money and all cash, all legal demands and all contracts were to be converted into Deutschmarks on one particular day, say 1 January 1991. This was a much more radical approach than the "10-Points Programme", formulated just two weeks earlier. It envisaged still a time span of almost a year. As the paper continued monetary stability would be essential, therefore, the total quantity of Deutschmarks should roughly correspond to the production potential of the unified economic area. According to calculations done by the research institute DIW labour productivity in the GDR would be about 45-60 percent of the West German level (in reality it was much lower, see below). To be on the conservative side Sarrazin proposed to calculate on the basis 40 percent. This would result in a production potential of the GDR in comparison with West Germany of:

[8.6 million economically active persons in the GDR/29.7 million in West Germany] $\cdot 0.4=0.116$.

Consequently the GDR would add some 11.6 percent to the West German production potential. Thus the quantity of Deutschmarks could rise by this amount without endangering monetary stability. This was very close to the monetary income of the GDR population, measured in GDR Marks, compared to the income of the West Germans (12.1 percent). In other words the income of the GDR population could be converted at a rate of 1:1 into Deutschmarks without endangering monetary stability. Some other calculations came to similar results.

These results were surprising insofar as most observers so far were inclined to consider that a conversion rate far below parity would be appropriate; these views were based on the point that in foreign trade an exchange rate of only 5:1 was used. However the point that the GDR Mark was almost at parity in its purchasing power of everyday consumer goods, whereas it was worth much less in foreign trade could be explained by a model formulated in 1964 by Bela Balassa: The foreign exchange rate was determined by "tradable" commodities ("cars"), but not by the non-tradables ("hair-cut") but the productivity in less developed countries was much lower as regards tradables than non-tradables. This, however, point at a fundamental dilemma: A conversion rate of $1: 1$ could seem perfectly reasonable when comparing non-tradables. The matter was, however, different when it came to manufacturing which would be exposed to foreign competition. For them with operating levels of productivity far below Western standards a conversion of 1:1 would be mortal-a point Sarrazin did not mention. As Sarrazin's paper continued, at the time of conversion the competences for monetary policy and provision of central-bank money should be transferred to the Bundesbank. All price subsidies ought to be abolished except for energy and housing. All remnants of the planned economy would disappear, the state-owned enterprises would gain independence and be removed from the state budget. 
In one respect the paper was astoundingly optimistic: By integrating the GDR economy into the Deutschmark area the reform process would gain a completely new quality: The "brain-wrenching" (hirnzermarternden) and almost unsolvable questions as to how to install a functioning price mechanism, competition and a functioning capital market quickly and without big social costs, "will disappear completely because on the day of the conversion all this will be there." It was not explained how "all this" could be in place by then. He was obviously hoping that the market forces would take care of that. At reaction time of zero.

Certainly as Sarrazin continued some problems were to be expected. For instance the industrial sector had been inflated in the GDR, employing about 20.9\% of the population. The corresponding figure in West Germany was $14.2 \%$. Here substantial redundancies would take place. On the other hand, the service sector, underdeveloped in the GDR, could absorb the employees made redundant from industry. Certainly there will be "transitional problems" (Übergangsprobleme). Therefore an unemployment insurance must be operational on the day of currency transition. Unavoidably and for a longer period it had to be financed with money from West Germany. All in all the paper shows that in the Ministry of Finance there was an awareness of considerable problems ahead.

\section{The federal government endorses monetary union}

On 30 January 1990 Finance Minister Theo Waigel met the heads of the Directorate-Generals (Abteilungen) of the Ministry. On that occasion he endorsed the idea of a monetary and economic union with the GDR. A few days later the officials in the Finance Ministry received the signal that also Kohl had accepted it (Sarrazin, 1994, p. 190).

In the meantime officials at the Chancellery were working on it as well. On 2 February 1990 they passed a dossier to Kohl. ${ }^{7}$ The authors were mainly interested in the place of a monetary union inside the general political situation. Currently, according to the authors, in public discussion, the problems of the economic reconstruction of the GDR held centre stage. They recommended that Kohl should again place himself at "the forefront of events" (an die Spitze der Bewegung), ${ }^{8}$ as he had done with his Ten-Point Programme. The authors saw two points as being central:

- The impression must be avoided that the government would be overtaken by events, and

\footnotetext{
${ }^{7}$ Nr. 157, Vorlage des Regierungsdirektors Mertes an Bundeskanzler Kohl. Bonn, 2. Februar 1990, Dokumente, 1998, pp. 749-753.

${ }^{8}$ Nr. 157, Vorlage des Regierungsdirektors Mertes an Bundeskanzler Kohl. Bonn, 2. Februar 1990, Dokumente, 1998, pp. 749-753, esp. p. 749.
} 
- A clear signal should be sent to people who contemplated leaving the GDR that the situation would improve in the not too distant future.

The first free elections in the GDR were scheduled for 18 March 1990 and election campaigns had started. The authors saw it as decisive that Kohl's partners in the GDR-an alliance of parties that was in the making-could soon present a "tangible" (griffiges) concept for the reconstruction of the GDR economy. The development of "confederate structures with the perspective of German unity" should also be discussed with the partners in the GDR. Therefore the authors prepared two papers, the draft of a statement about the next steps towards political unification and a "keyword concept" about realizing Germany's economic unity.

The draft of the political statement ${ }^{9}$ mentioned economic and monetary union as the first step. Immediately after the elections on March 18 common government committees should work towards a harmonization of the legal system. With the partners in the Western Alliance common initiatives should be taken in order to develop common security structures within the framework of the OSCE to overcome the division of the European continent. The united Germany would also be an active part of the European Community; the aim being a free and united Germany in a free and united Europe.

Again as a surprise for everyone, on 6 February, Kohl announced his intention to start negotiations with the GDR about an economic and monetary union. According to Horst Teltschik, director of Department 2 (foreign policy) in the Chancellery, a monetary union would be the first practical step towards unification but was it wise for Kohl to announce it shortly before a planned tour to Moscow? Nothing was cleared with the Western Allies. But Rudolf Seiters, the chief of the Chancellery, and Teltschik nevertheless recommended such a step. It was only a declaration of intent so there was time enough to undertake the "necessary coordination" (innere und äußere Abstimmung). According to Teltschik, the decision to go public was actually taken the very same day. Lothar Späth, Prime Minister in Baden-Württemberg (and rival to Kohl), intended to make a big political declaration the next day, demanding, among other things a monetary union, and therefore Teltschik recommended that Kohl take the initiative himself (Teltschik, 1991, p. 129).

\section{The cabinet meeting on 7 February 1990}

On 7 February the federal cabinet met. Karl-Otto Pöhl (Bundesbank) and the chairmen of the government parties and the parliamentary groups also participated. Teltschik gave a rather detailed account of the session. According to him Kohl argued that the situation in the GDR had developed more dramati-

\footnotetext{
${ }^{9}$ Nr. 157 A. Statement, ibid., p. 751.
} 
cally than expected (Teltschik, 1991, p. 130ff). ${ }^{10}$ The authority of the state had collapsed and fear was spreading. Money alone would not help, profound reforms were necessary. Therefore the day before he had agreed with the party chairmen Otto Graf Lambsdorff(FDP, liberals) and Theo Waigel (CSU, Bavarian Christian Democrats) that immediately after the elections in the GDR negotiations about the creation of federal structures should begin. The aim was to stabilize the GDR and as this was also in the interest of the Soviet Union an agreement was possible.

Finance Minister Waigel declared that everyone would have preferred a step by step procedure which, however, would have taken time. As Waigel explained, there were three possible ways towards a currency union. Number one was the "coronation" way-a currency union after the introduction of all necessary economic reforms. A second possibility was a fixed exchange rate between the Deutschmark and the GDR Mark which the Bundesbank had to guarantee. The introduction of the Deutschmark as the only currency was a third way; in this case, the Bundesbank had to take control over fiscal and monetary policy. The GDR had to adopt West Germany's economic system. In particular on the labour market transitional problems had to be expected.

Karl Otto Pöhl, President of the Bundesbank, had previously expressed skepticism, but declared now that he saw no substantial differences (emphasis mine, WZ). The federal government had to decide and to take responsibility because the GDR was obviously in a process of dissolution. Certainly it would be more reasonable to make the Mark of the GDR convertible gradually, but such a slow procedure was not possible anymore; therefore, the Chancellor's concept of an economic and monetary union was right but gigantic (riesige) transfer payments would be necessary. However at the end Germany would be more wealthy than today. At the meeting there was agreement to proceed with monetary union immediately after the elections. So far the consensus included some leading Social Democrats. On 2 February Ingrid Mathäus-Meier and Wolfgang Roth demanded that negotiations on a monetary union should start immediately after the elections in the GDR, within a period up to the beginning of $1991 .{ }^{11}$

The federal cabinet decided to form a cabinet committee "German Unity", under the leadership of Kohl or in his absence Seiters. ${ }^{12}$ Six working groups were to be established each under the direction (Federführung) of a particular ministry. These groups were: Monetary Union and Financial Issues (Federführung:

${ }^{10}$ Teltschik refers extensively to this meeting. He does not say whether he could use the minutes, or whether he was told afterwards about it. At least, preparing cabinet meetings and assessing them was part of his duties.

${ }^{11}$ Nr. 163. Vermerk des Regierungsdirektors Nehring. Bonn, 6. Februar 1990, Dokumente, 1998, p. 761. The date is presumably wrong. The author refers to decisions taken in the cabinet meeting on 7 February.

${ }^{12}$ Nr. 161. Tischvorlage des Chefs des Bundeskanzleramtes für die Kabinettssitzung am 7. Februar 1990. Bonn, 5. Februar 1990, Dokumente, 1998, p. 759. 
Ministry of Finances); Economic Union, Energy and Environment (Ministry of Economy), Equalization of Working and Social Conditions (Ministry of Labour), Legal matters, in particular the Alignment of Legal Norms (Ministry of Justice); State Institutions and Public Order (Ministry of the Interior) and finally, Matters of Foreign and Security Policy (Ministry of Foreign Affairs). Work started to overhaul the GDR-completely.

\section{Waigel's revised budget: an exercise in very optimistic calculations}

Waigel had to present a revised federal budget to the Bundestag to cover any anticipated new expenses. As he explained in a letter to the parliamentary group of CDU and CSU, the new budget was a political signal about the readiness of the federal government to contribute to the economic stabilization of the GDR. ${ }^{13}$ As to the expected fiscal burdens Waigel's budget revision was of a remarkable optimism. Overall federal expenses were to rise from 300 to 307 billion Deutschmarks; net credit increased by only 6.54 billion Deutschmarks to 33.48 billion. ${ }^{14}$ The necessary investment for the modernization of the GDR economy should mainly be financed through private investment. State aid was of subsidiary character directed mainly towards infrastructure, dissemination of know-how and humanitarian aid.

As Waigel pointed out ${ }^{15}$ the most important point for most GDR citizens was to achieve a standard of living on a par with the Federal Republic. However differences in the standard of living were due to differences in productivity. The most promising way to raise it would be the integration (Verklammerung) of the German economies through a currency union based on profound economic reforms. Complementary to the mobilization of private capital, a modern and efficient infrastructure (roads, telecom, reconstruction of the towns, etc.) had to be put in place. West German help has to be limited to a fond of foreign currency, to relieve bottlenecks, for humanitarian aid, e.g. medicines, assistance for small and medium-sized companies and for infrastructure and environmental projects. According to Waigel European integration could serve as an example: Real income in Spain and Portugal for example could be raised only through foreign direct investment and through mobilizing the private labour force. Help from the EU Structural Funds can have only a supplementary character. Due to the strong economic dynamism realized since 1982 (when the Kohl government took over) help for the GDR can be financed basically through the increases in

\footnotetext{
${ }^{13}$ Nr. 165. Schreiben des Bundesministers Waigel an die Mitglieder der Fraktion der CDU/ CSU im Deutschen Bundestag. Bonn, 7. Februar 1990. Dokumente, 1998, p. $766 f$.

${ }^{14}$ Nr. 165A. Nachtrag zum Bundeshaushalt 1990, Dokumente, 1998, pp. $767 \mathrm{f}$.

${ }^{15}$ Nr. 165B. Währungsunion mit Wirtschaftsreform, Dokumente, 1998, pp. 768-770.
} 
GDP (!). As Waigel continued German unity will even become an additional growth programme. The challenges in the other part of Germany will liberate dynamic forces; also the markets of central and Eastern Europe will offer new possibilities for German companies. However, transitional problems had to be expected. He mentioned a "temporary" redundancy of the labour force, securing the purchase power of pensions and servicing the external debt of the GDR.

These last points show that Waigel had some sense of the problems to come. But otherwise this is a document of striking optimism, in particular perhaps the point that the financial burdens would be comparable to EU's regional policy. Did the minister not know better? Or was this a demonstrative optimism with the view to the coming elections in the GDR?

Another factor contributing to overoptimistic expectations has been the mythology about the currency reform of 1948. According to this popular myth the introduction of the Deutschmark in June 1948, in combination with liberal reforms such as abolition of rationing, had ignited the West German economic miracle. Economic historical research had modified this picture substantially and underlined the importance of very benign circumstances in 1948. By then West Germany had large reserves of modern industrial capacities (in spite of the war losses) and a highly qualified pool of manpower. Also the system of economic law was modern. None of these conditions were present in the GDR in 1990: Its industry was outdated and delapidated, most employees were not used to modern technology and the legal system was heavily distorted. Nevertheless many politicians entertained the illusion that bringing in the Deutschmark would spark a new economic miracle. For instance Count Lambsdorff, the leader of the liberals, declared in April 1990: "What we achieved in 1948, also the GDR can do in 1990" (Abelshauser, 2011, p. 444). Ingrid Mathäus-Meier, the spokeswoman for the Social Democrats, expressed in February 1990: "I am of the firm conviction that an introduction of the Deutschmark would be the start signal for an 'economic miracle' in the GDR" (Abelshauser, 2011, p. 444).

\section{An intervention from academia}

However not everyone shared this optimism. On 9 February 1990 Kohl received a fax from Professor Hans K. Schneider, the chairman of the expert committee for assessing the macroeconomic development, an advisory board for the government: "With deep concerns (Mit Besorgnis) the expert committee follows recent considerations pushing for a fast introduction of a currency union with the GDR." ${ }^{16}$ The federal cabinet had emphasized the connec-

\footnotetext{
${ }^{16}$ Nr. 168. Schreiben des Vorsitzenden des Sachverständigenrats zur Begutachtung der gesamtwirtschaftlichen Entwicklung, Schneider, an Bundeskanzler Kohl. Wiesbaden, 9. Februar 1990.
} 
tion between currency reform and economic reform. However as Schneider pointed out, the sequence of the steps was of decisive importance and currency union should not be the first step. The common currency would make the differences in income immediately transparent and demands for a correction would be hard to refuse. Nominal wages would rise ahead of productivity, which in turn would undermine the GDR as a location for production. This would generate pressure on the Federal Republic to create public transfers in order to reduce the differences in income. Public budgets would have to shoulder gigantic (riesige) burdens. Raising taxes will become unavoidable and public transfers had to be used for consumptive spending instead of improving the infrastructure.

Schneider continued that as long as the prices in the GDR were distorted and conditions for investments unclear a currency union would actually weaken production. GDR products often did not match demand, qualitatively and quantitatively; GDR consumers would therefore channel their demand towards West German or foreign goods at the expense of demand for GDR products. GDR companies would be exposed to international competition overnight which they could not survive. These effects could be avoided only if the companies gained competitiveness beforehand. A minimum requirement would be company reform enabling them to react flexibly to market conditions. Furthermore the prices of GDR products did not correspond to costs. Some prices were artificially low due to heavy subsidies. These goods the companies could export but the GDR would actually make losses, due to the high real costs.

Prior to a currency union the problem of the monetary overhang had to be solved (the experts had proposed the selling of shares of the "people-owned" industry to savers). The reform of price mechanisms would have to have made good progress and banking and credit ought to be adapted to market conditions. Only if these conditions are in place can the currency policy become "more courageous".

Schneider's text exhibits several prophetic qualities. It is, however, not certain that his proposed sequence of economic reform and then currency union could have worked. Was it possible to reform the state-owned companies, introduce hard-budget constraints and make them reactive to market forces, under the conditions of a rapidly dissolving GDR? As we have seen, at the cabinet meeting on 7 February, Finance Minister Waigel, Bundesbank Chief Pöhl and other participants accepted the priority of economic reform in principle, expressed, however, that it was too late. This position was also widespread in the Finance Ministry. Furthermore the GDR population, or at least a substantial parts of it, pressed for rapid monetary union. During demonstrations, placards were shown: "If the Deutschmark comes, we'll stay. But if it doesn't, we'll go there." Under conditions of approaching elections demands such as these carried weight. Schneider's paper did not seem to have influenced matters. There was already consensus at cabinet level to go for a rapid currency reform. 


\section{First talks between Bonn and East Berlin on monetary union}

At about the same time (11 February 1990) the Soviet News Agency TASS made it public that General Secretary Michail S. Gorbatchov had said at a meeting with Chancellor Kohl that the Germans themselves had to solve the question of German unity (Sarrazin, 1994, p. 194). Basically the way to German unity was free. The following negotiations were conducted on two tracks: The internal problems, e.g. currency union, were agreed in bilateral discussions between the Federal Republic and the GDR, whereas the four Allied Powers and the two German states ("Four Plus Two") negotiated the international questions.

In December 1989 the GDR government and the main opposition groups had formed a "Round Table" and at the beginning of February representatives of the main opposition groups entered the government as ministers without portfolio. Delegations of the two governments met in Bonn on 13 February. ${ }^{17}$ Prime Minister Modrow declared that they accepted the formation of an expert committee for the discussion of the currency union. All preparatory work should be accomplished by 18 March so that negotiations could start soon after the election. But nothing should be done "overhastily", in particular in respect of the foreign political development. Rainer Eppelmann, theologian representing the opposition group Demokratischer Aufbruch, said the development needed more time. The people should have the possibility to take along a "piece of identity". Matthias Platzeck (Green League, later SPD) underlined the importance of protecting the self-determination of the GDR. The procedure of the federal government and the intermingling of the West German parties in the GDR election campaign created, however, the impression of foreign domination. Vice Premier Christa Luft, a representative of the old regime, found a currency union "fascinating" and desirable. However the population could not accept that they had to make big sacrifices for a second time after the Second World War.

Kohl pointed out the importance of the coming OSCE summit, presumably in November: Until then the both sides should have reached an agreement on the inner structure of the future Germany. ${ }^{18}$ The Chancellor was concerned that the OSCE summit could turn into a big conference on Germany; he was well aware of the fact that many politicians outside Germany watched German unification with apprehension, out of security concerns, but also for economic reasons. In Germany also many people were worried, in the West

\footnotetext{
${ }^{17}$ Nr. 179. Delegationsgespräch des Bundeskanzlers Kohl mit Ministerpräsident Modrow. Bonn, 13. Februar 1990. Dokumente, 1998, p. 821-826.

${ }^{18}$ Nr. 179. Delegationsgespräch des Bundeskanzlers Kohl mit Ministerpräsident Modrow. Bonn, 13. Februar 1990. Dokumente, 1998, p. 826.
} 
mainly about pensions, rising interest rates and stability of the currency, in the GDR as regards jobs, pensions or saving accounts. The way ahead would be difficult but he saw the chance that the GDR could make a "gigantic move upwards" (einen gewaltigen Aufschwung): "Conditions for that are exceptionally favourable."

The GDR representatives had pointed out some important aspects: Huge parts of the GDR population felt overwhelmed by events over which they had very little influence. The feeling was probably widespread that the citizens of the GDR had a kind of "right" to a West German standard of living. However this could not be done without a West German standard of productivity, something which Bonn could not just donate; it required profound changes and endeavours on the part of the GDR population; something which seemingly was felt to be very unjust.

A few days later, on 20 February, the agreed-upon expert commission met for the first time, in East Berlin. Both sides had sent high-ranking representatives, aided by numerous officials as advisors (Sarrazin, 1994, p. 195). Horst Köhler, the State Secretary in the Finance Ministry, led the federal delegation. The GDR had sent mainly experts from the old regime, for instance the Minister for Light Industry. Their leader was Werner Romberg, social democrat and minister in Modrow's cabinet.

Thilo Sarrazin followed the meetings closely: "As to the substance, regarding the conditionality of the offer and the coherence of the conditions, the federal part had to be very strict. But this had to happen with tact and flexibility" (Sarrazin, 1994, p. 196). The GDR side tried to preserve elements of its system. Only stepwise, as Sarrazin put it, did they realize that because of the short time spans there were no alternatives to an almost complete adoption of West German economic and social legislation?

On 13 March the expert commission finalized a confidential interim report. ${ }^{19}$ Both sides had agreed that the envisaged monetary and economic union would be a decisive step towards German unity. They had reached consensus that the Deutschmark should be introduced on a specific date, accompanied by the creation of the legal conditions of a market economy. The influx of private capital would be necessary; the Bundesbank will be responsible for monetary policy, based on the principle of monetary stability. Some questions still needed further elaboration, for instance assistance for structural adaptation and the modalities of the currency conversion. Further negotiations had to wait until the formation of a new government after the election.

${ }^{19}$ N5. 219A. Zwischenbericht der Expertenkommission zur Vorbereitung einer Währungsunion und Wirtschaftsgemeinschaft zwischen der Bundesrepublik Deutschland und der Deutschen Demokratischen Republik, Dokumente, 1998, pp. 948-950. 


\section{The GDR elections of 18 March}

The first free elections on 18 March 1990 turned, as the magazine Der Spiegel put it, into "Kohl's triumph" (Rödder, 2009, p. 224). The Christian Democratic Allianz für Germany-a cooperation between three groupings-received $48 \%$ of the votes. The Social Democrats gained only 22\%. The Partei des Demokratischen Sozialismus (PDS), the successor of the communist SED, had more than expected, 16\%. Together with the liberal FDP (5\%), the Christian Democrats could thus muster a solid, absolute majority in the new Volkskammer. The result was quite unexpected. Opinion polls had predicted a social democratic victory. Kohl's strategy, a drive towards German unification, the first and decisive step being the "economic, monetary and social union" (as it became termed during the campaign) was vindicated; the vote was generally interpreted as a kind of plebiscite.

Negotiations for the formation of a government were not easy, not before 18 April could the Christian Democrat Lothar de Maizière present his new cabinet, formed of Christian Democrats, Liberals and Social Democrats. Their inclusion was necessary because a constitutional majority was needed for the profound changes ahead. On 25 April the official delegations of the governments met to negotiate the monetary union (Sarrazin, 1994, p. 205). The time between the end of the expert talks (13 March) and the start of the regular negotiations was used intensively in the federal Finance Ministry and the Bundesbank.

The more the West German experts became familiar with the problems, the more it became clear to them that in many fields the only solution was a wholesale import of West German legislation. Time pressure was mounting: 1 July appeared ever more as the requisite date. Because of the holiday season the next possible date would be 1 October, which seemed to be too late because of the political pressure from the GDR. At the latest by the beginning of April, Kohl had opted for 1 July. Also the new GDR government declared for this date (Tietmeyer, 1994, p. 63). Officials in the Finance Ministry, the Bundesbank and the Chancellery estimated that implementing the monetary union would take some eight weeks. This meant the agreement should be ready by beginning of May.

On 27 March Minister Waigel ordered the commencement of the preparations for the treaty. On Friday, 30 March and the following Saturday and Sunday up to 100 officials from all departments concerned met in the Finance Ministry to prepare the comprehensive treaty. It was an advantage that the large ministerial bureaucracy in Bonn had experts even for very unusual problems, but also broad-minded synthesizers. Bruno Schmidt-Bleibtreu, head of Department 5 (which was also responsible for constitutional questions) presided calmly over what seemed to be chaos. Sarrazin sensed a shift: Until then it was economists supported by lawyers who drove the discussions. Now leadership was transferred to lawyers (Sarrazin, 1994, p. 201). 
The West German Basic Law contained two possibilities for unification: East and West Germany could together draft a new constitution; or, according to Article 23, the newly-created Länder of the GDR could become members of the Federal Republic of Germany. This meant also taking over almost the whole legislative system of West Germany. Given the point that the monetary union implied the import of large areas of West German legislation anyhow, a new constitution had to a very large extent to be a copy of the old. Furthermore there was the time pressure but drafting a new constitution would unavoidably be a lengthy process. However for a not inconsiderable number of people in the GDR a process according to Article 23 had some bitter tastes: It was not a process where two equal partners jointly created something new, but one where one part basically continued as before, whereas the other had to undergo a very profound adaptation to the other.

\section{The Bundesbank resolution}

On 30 March Bundesbank President Pöhl sent a letter to Kohl informing him about a resolution which the Zentralbankrat had decided upon. ${ }^{20}$ After "a long and careful preparation", the Bundesbank leadership concluded that the conversion rate of the GDR Mark to the Deutschmark should be 2:1 also as regards salaries and wages with a view to the competitiveness of the GDR. A rate of 1:1 (as demanded by many) would generate levels of costs and indebtedness at which most companies could not survive international competition. The result would possibly be a dramatic increase of unemployment. This was a very precise prediction.

As Pöhl continued a rate of 2:1 would only seemingly halve pensions and wages. The pensions would be calculated anew according to the West German formula with the result that the GDR pensioners would actually get higher pensions in Deutschmarks than currently in GDR Marks. As to wages companies and public sector administrations will have to negotiate new salaries and a rate of 2:1 will allow for the necessary differentiation, whereas 1:1 implied the risk of starting at a level which would be far too high.

Bank accounts should be converted at 2:1. For savers in real terms it would imply a revaluation of their accounts. The Bundesbank recommended, however, the conversion of savings' accounts up to 2,000 GDR Marks at 1:1, to make the general rate of 2:1 "politically-psychologically acceptable". On the other hand a general conversion rate of 1:1 of the savings' accounts (as often demanded) would imply a considerable enlargement of the quantity of money

\footnotetext{
${ }^{20}$ Nr. 239. Schreiben des Bundesbankpräsidenten Pöhl an Bundeskanzler Kohl. Frankfurt (Main), 30 März 1990. Nr 239A Entschließung des Zentralbanrates, Dokumente, 1998, pp. 102-104.
} 
which would put monetary stability at risk, with negative effects on financial markets. Pöhl finally pointed out that the Bundesbank would not publish its resolution. However he had no objections if the Chancellor would make "public use" of it. Kohl seems to have done exactly this, presumably in order to "test the waters". Immediately the notion of converting wages and pensions at a rate of 2:1 sparked widespread protests in the GDR. During the election campaign many West German politicians-not Kohl (Tietmeyer, 1994, p. 69)-had talked of 1:1. The new government of the GDR also insisted on 1:1 and on a comprehensive "monetary, economic and social union".

Hans Tietmeyer, who at the beginning of April took over the leadership of the West German negotiating team, commented in 1994 that he had preferred to introduce the "social union" only step by step; for instance the highly complex (and often rigid) West German labour and social legislation should not be applied in the first place, allowing for more flexibility in the face of the coming economic shocks. But this turned out to be impossible. The GDR side was adamant.

\section{The final negotiations}

Soon after the formation of the GDR government Tietmeyer and Johannes Ludewig from the Chancellery went to East Berlin to discuss the currency conversion with Lothar de Maizière and other GDR politicians. Tietmeyer and Ludewig had some success in transmitting the message that a conversion of all bank accounts at 1:1 would create a dangerous expansion of the quantity of money. But the GDR side was uncompromising as to salaries and wages. As Tietmeyer had noticed many politicians in Bonn also took this for granted. The idea that higher wages required a corresponding level of productivity seems to have been alien to many.

On 19 April and the following days in Bonn the guidelines for the coming negotiations were finalized. For Kohl it was important that GDR pensioners would soon receive the comparatively high pensions according to the West German system. According to him the fruits of their labour in the GDR had been wasted, they having no responsibility for that. Kohl seemed to be willing to accept heavy new burdens for the Federal budget.

The official negotiations with the GDR government started on 17 April. Prime Minister de Maizière asked the West German delegation leaders for a confidential meeting. In the evening of 23 April, Tietmeyer and Interior Minister Schäuble visited him in his office. It had dawned on de Maizière that GDR companies would have severe difficulties as soon they had to pay their employees Deutschmarks at a rate of 1:1. De Maizière mentioned the possibility of subsidies from the Federal government. Interestingly de Maizière did not mention 
the possibility of dropping the $1: 1$ rate. He seemed to think that in case the rate of 1:1 created problems it was Bonn's duty to cover the expense.

Two days later the two delegations met for the first time. The GDR delegation was unprepared. Their leader Günther Krause told Tietmeyer later that de Maizière had given him the draft treaty some ten minutes before the session (Tietmeyer, 1994, p. 10). Krause also told Tietmeyer that the GDR government was happy that the West German side had already prepared such a comprehensive document. At the next meeting on 27 April the GDR delegation declared that they could accept the draft as basis for the negotiations but that they had some reservations. For instance, they wanted an explicit recognition of the "common property in its various forms", obviously trying to save a part of the GDR socialism, but this was not compatible with West German law and thus had no chance of being accepted.

In Bonn on 29 April there were intensive discussions between Tietmeyer, Bundesbank Vice President Helmut Schlesinger and the state secretaries of the Finance, Economic and Labour ministries. Before taking over the leadership of the negotiations, Tietmeyer worked at the leadership of the Bundesbank; together with Schlesinger he argued for the line of the resoluition of the Zentralbankrat The round reached consensus on the general rate of 2:1 for accounts and legal claims. However, as the state secretaries pointed out, it would be politically acceptable only if the amount which could be converted 1:1 would be higher than the 2000 Mark which the Zentralbankrat had proposed. As to wages the state secretaries saw 2:1 as unrealistic because of the intransigence of the GDR government and the public declarations of leading politicians of government and opposition in Bonn (Tietmeyer, 1994, p. 78f).

Tietmeyer tried some damage limitation and proposed that the wages should be counted as they were on 1 January 1990. In the meantime a wave of generous wage rises had swept across the GDR which the the authorities and company leaderships had not being able to resist. The matter was left undecided for the time being.

Kohl pressed for the finding of a solution soon as he wanted to put an end to the many speculations circulating in the press. A row of further discussions followed, internally in Bonn and with the GDR delegation. The GDR side did not insist anymore on a 1:1 conversion of savings' accounts and legal demands and a cancellation of all debts of the "people-owned" companies, but they remained stubborn as to wages.

The de-facto decisions were taken on the evening of 1 May at a meeting of the leaders of the coalition parties. They accepted the conversion of savings and legal claims at 2:1. Per person an amount of 2,000/4,000/6,000 Marks could be converted 1:1 according to age. As to wages and other current payments they retained the fateful 1:1; this was also the rate for pensions. Tietmeyer's proposal to use the date of 1 January 1990 found support at the beginning but then resistance gained momentum. Tietmeyer got the impression that they thought 
this was not acceptable for the GDR population. Thus, also in this round, the argument of competitiveness did not carry much weight. Only a date of 1 May was accepted in order to remove an incentive for further pay rises before the conversion. On 4 May the two delegations formally endorsed the agreement (Tietmeyer, 1994, pp. 84-88).

In the meantime State Secretary Klaus Kinkel, Ministry of Justice, had developed guidelines for solving the vexed problems of property and compensation for expropriations made during the GDR time. He proposed the principle of "Restitution instead of Compensation". This was seemingly fair and had the advantage that Bonn did not have to pay for compensation. On the other hand several waves of expropriations and sales had created complex layers of claims which came to delay investments considerably. These could go back to the Third Reich when the Nazis had expropriated Jewish property which then was taken over by the Soviet military authority or the GDR. During the "4 plus 2" negotiations the Soviet Union had insisted that expropriations during the years 1945-1949 could not be restituted. Declaring them illegal would taint the reputation of the Soviet Union. This concerned mainly the land confiscated during the land reform of 1945.

In the last rounds of the negotiations the GDR Ministry of Economics proposed to impose import taxes or quotas on goods entering the GDR (Tietmeyer, 1994, pp. 95-105). The problem of competiveness of GDR industry had dawned also on them. Imposing taxes or quotas was, of course, impracticable under conditions of open borders. There were also discussions on allowing GDR companies to reach particular agreements on their wage levels. The West German trade unions, fearing low-wage competition, intervened in Bonn; there were also controversies in the GDR government. In the end Günther Krause, the leader of the GDR delegation, declared pointedly that regarding the aim of reaching a full political unity soon, special agreements could not be accepted even if they were economically fully justified (Tietmeyer, 1994, p. 107). The logic behind this argumentation is not really clear.

By now it was clear to everyone in Bonn that the federal government had to expect "gigantic" burdens. On 15 May a Koalitionsrunde agreed on the establishment of a Fond Deutsche Einheit, a Fund of German Unity, which could borrow on the capital markets. The Federal Government and the West German Länder would service the debt jointly (Tietmeyer, 1994, p. 112). This way the ordinary budget would be protected. This had optical advantages but also allowed for more flexibility than the ordinary budget procedures.

On Friday, 18 May the two finance ministers signed the text at a solemn ceremony in the Palais Schaumburg in Bonn. The Deutschmark was to be introduced in the GDR on 1 July 1990. From a technical and logistical point of view the operation was conducted almost glitch-free. 


\section{The conversion on 1 July 1990 and its consequences}

Pensioners and many employees in state administrations experienced substantial gains in real income. Other were not so lucky. Productivity levels in the GDR differed widely; on average it was about one sixth of the West German level. After the conversion wages were at about one third of the West German level (Sinn and Sinn, 1992, pp. 21 and 225). This was equivalent to a revaluation of $100 \%$. Wages remained far above productivity for years to come. In 1991 the East German unit costs were at 151\% of the Western level and in 1996 still 130\% (DIW-Wochenbericht, 1997).

As predicted by Professor Schneider GDR consumers preferred West German products during the first months. In addition the initial high hopes that the markets in the former Soviet Bloc could stabilize East German production (Klemm, 1994, pp. 137) became disappointed too. These countries did not have enough Deutschmarks to pay for it.

In addition many of the sites of the companies "owned by the people" were poisoned by toxic waste and other ecological burdens which had to be removed by their future owners. Under these conditions they could be sold only at negative prices. In the end, by 31 May 1994 the Treuhand, the institution in charge of privatizations, had accumulated a debt of 275 billion Deutschmarks (Priewe, 1994, p. 23). When discussions on monetary union began there were widespread expectations that the "people-owned" companies were valuable assets.

The GDR economy already began declining in October 1989. After monetary union it fell almost vertically. In the first half of 1991 the index of industrial production had declined to one third (!), compared to the level in the first half of 1990. Gross Domestic Product, which shrank less violently, had fallen by "only" 35\% (Akerlof, Rose, Yellen, \& Hessenius, p. 8). Unemployment was virtually unknown before the fall of the Berlin Wall. By 1992 more than a third of the labour force was outside productive employment; in 1996, it was still about a quarter. In 19898.9 million people were gainfully employed, in 1996 6.4 million. 2.5 million Jobs had disappeared (Wegner, 1996, p. 21). Small wonder that emigration (which the monetary union should have stopped) continued for many years.

Only an unintended Hyper-Keynesianism prevented a social catastrophe. The construction of the monetary, economic and social union implied high transfers to East Germany in the form of pensions, unemployment subsidies, support for the public sector and others. In 1991131 billion Deutschmarks flowed to the East as public net transfers. This was the equivalent of $64 \%$ (!) of the East German GDP or 5\% of West Germany's. In 1996 it was still 35\% of the East German and 4.3\% of the West German GDP (Wegner, 1996, p. 20). These transfers did have some effect and production started rising again. In 1991 the real GDP per inhabitant was at approximately $31 \%$ of the West German level. 
It rose to $54 \%$ in 1996 . Private consumption was higher, not least due to the transfers, and rose from 31 to 54\% in 1995 (Wegner, 1996, p. 16). ${ }^{21}$

All in all there has been a process of convergence. This pertained not just to economic indicators but to many fields of society where the GDR exhibited "deficits of modernization", for instance an underdeveloped relative autonomy of the social subsystems (e.g. education), tendencies of social closure in the education system, or ethnic homogeneity of neighbourhoods (Geißler, 2011, p. 364-367). But the convergence has been slow and is still not finished and certainly it was not the Wirtschaftswunder of the kind West Germany experienced at the end of the 1940s and during the 1950s.

\section{Conclusions}

How can the special design of the currency union of 1 July 1990 be explained? Point one, many opinions were formed in a statistical mist. When the view became clearer during the end phase of the negotiations many opinions remained fixed. Furthermore decisions were made under time pressure. In principle officials in Bonn adhered to the "coronation theory", according to which a monetary union should be built only at the end of comprehensive reforms which created the necessary conditions for it. This was also the line which Bonn's representatives followed during the negotiations leading to the introduction of the euro (Dyson \& Featherstone, 1999, p. 54). But such a strategy became unviable, due to the rapid erosion of the GDR institutions. Furthermore the high levels of emigration weakened the GDR economy on a daily basis. At the Bonn cabinet meeting of 11 February there was already a consensus that the wholesale introduction of the Deutschmark at a not too distant point in time was the only practical option. This consensus included the Bundesbank, the top-level in the Finance Ministry and leading Social Democrats. It is thus not correct when Rudolf Hickel and Jan Priewe conjectured that the decision for monetary union was done within few days and due to a unilateral decision of the federal Chancellor within the circle of his closest advisors (Priewe \& Hickel, 1991, p. 81).

Among the general public and many politicians in spring 1990 over-optimistic expectations prevailed. Here the superficial memories of the Währungsreform of 1948 played a crucial role. It fitted all too well with wide-spread liberal ideas about the benefits of free markets. The point that markets can work only under the right conditions was overlooked.

In general it appears that the Bundesbank was the institution that was best informed. It could not decide matters but it had some influence as advisor. The

${ }^{21}$ These figures were revised later. The Jahresbericht (2018) put the GDP per person in 1991 at $43 \%$ of the West German level. 
modalities of the currency union were designed mainly according to the lines of the Zentralbankrat resolution of 30 March 1990. However, with one important exception: the conversion of wages. Even in April and May when it had dawned on many what a 1:1 conversion meant for the GDR industry not even Tietmeyer's modest proposal of using wages as of January 1990 was accepted. Remarkably the GDR side did not even accept some flexibility for particularly vulnerable companies-"however good the economic arguments were."

This brings us to another important actor: The people, or at least substantial parts of it. It was the multiplying of opposition activities and mass demonstrations which led to the fall of the Wall and the downfall of the SED dictatorship. "The people" also influenced matters substantially by migrating to West Germany and West Berlin thus putting pressure on Bonn and East Berlin. The elections of March 18th were seen as a plebiscite in favour of Kohl's policy. Thereafter the rapid introduction of the Deutschmark and unification soon after was the "only game in town".

The "power of the people" had, however, a problematic side. Their knowledge about the market economy and its brutalities was insufficient. They might have heard about closing steel plants and unemployment in West Germany. But this was all rather abstract. Their own experience for decades had been that jobs were virtually invulnerable and that the level of salaries was determined arbitrarily. Consequently they saw no reason why their "moral right" of a 1:1 conversion should not be fulfilled. So profoundly was this belief apparently entrenched (we do not know its exact extent) that hardly any politician dared to go against it. Even when they knew that a train crash was coming. Some politicians found consolation in the conviction that market forces would correct disequilibria. This was not completely wrong. But sometimes this takes a really long time.

\section{References}

Abelshauser, W. (2011). Deutsche Wirtschaftsgeschichte. Von 1945 bis zur Gegenwart. München: C.H. Beck.

DIW-Wochenbericht. (1997). No. 17.

Akerlof, G. A., Rose, A. K., Yellen, J. L., \& Hessenius, H. (1991). East Germany in from the Cold: The economic aftermath of the currency union. Brookings Papers on Economic Activity, 1: 1-106.

Busch, U. (2010). Die Währungsunion am 1. Juli 1990: Wirtschaftspolitische Fehlleistung mit Folgen. Jahrbuch für Forschungen zur Geschichte der Arbeiterbewegung, 2, 5-24.

Diekmann, K. \& Reuth, R. G. (1996). Helmut Kohl: "Ich wollte Deutschlands Einheit". Berlin: Propyläen.

Dokumente zur Deutschlandpolitik. (1998). Deutsche Einheit. Sonderedition aus den Akten des Bundeskanzleramtes 1989/1990. Bearbeitet von H. Jürgen Küsters, \& D. Hofmann. München: R. Oldenbourg Verlag. 
Dyson, K., \& Featherstone, K. (1999). The road to Maastrich. Negotiating economic and monetary union. Oxford University Press.

Geißler, R. (2011). Die Sozialstruktur Deutschlands. Zur gesellschaftlichen Entwicklung mit einer Bilanz zur Wiedervereinigung (6 Auflage). Wiesbaden: VS Verlag für Sozialwissenschaften.

Jahresbericht der Bundesregierung zum Stand der Deutschen Einheit. (2018). Berlin.

Klemm, P. (1994). Die Verhandlungen über die deutsch-deutsche Währungsunion. In T. Waigel, \& M. Schell (Eds.), Tage, die Deutschland und die Welt veränderten: Vom Mauerfall zum Kaukasus: Die deutsche Währungsunion (pp. 135-148). München: Edition Ferenczy bei Bruckmann.

Küsters, H. J., Entscheidung für die deutsche Einheit. (1998). In Dokumente zur Deutschlandpolitik (pp. 21-236). Deutsche Einheit. Sonderedition aus den Akten des Bundeskanzleramtes 1989/1990. Bearbeitet von H. Jürgen Küsters, \& D. Hofmann. München: R. Oldenbourg Verlag.

Priewe, J. (1994). Die Folgen der schnellen Privatisierung der Treuhandanstalt. Eine vorläufige Schlußbilanz. Aus Politik und Zeitgeschichte, 43-44.

Priewe, J., \& Hickel, R. (1991), Der Preis der Einheit. Bilanz und Perspektiven der deutschen Vereinigung. Frankfurt am Main: Fischer Taschenbuch Verlag.

Rödder, A. (2009). Deutschland einig Vaterland. Die Geschichte der Wiedervereinigung. München: C.H. Beck.

Roesler, J. (2010). Ein anderes Deutschland war möglich. Alternative Projekte für das wirtschaftliche Zusammengehen beider deutschen Staaten. Jahrbuch für Forschungen zur Geschichte der Arbeiterbewegung, 2, 34-46.

Sarrazin, Th. (1994). Die Entstehung und Umsetzung des Konzeptes der deutschen Wirtschafts- und Währungsunion. In T. Waigel, \& M. Schell (Eds.), Tage, die Deutschland und die Welt veränderten: Vom Mauerfall zum Kaukasus: Die deutsche Währungsunion (pp. 160-225). München: Edition Ferenczy bei Bruckmann.

Schäuble, W. (1993). Der Vertrag. Wie ich über die deutsche Einheit verhandelte. Aktualisierte Taschenbuchausgabe. Mit einem Vorwort zur Taschenbuchausgabe von W. Schäuble. Herausgegeben von D. Koch, \& K. Wirtgen. München: Droemersche Verlagsanstalt Th. Knaur Nachf.

Sinn, G., \& Sinn, H. W. (1992). Kaltstart. Volkswirtschaftliche Aspekte der deutschen Vereining. Tübingen: J.C.B. Mohr.

Teltschik, H. (1991). 329 Tage. Innenansichtungen der Einigung. München: Siedler.

Tietmeyer, H. (1994). Erinnerungen an die Vertragsverhandlungen. T. Waigel, \& M. Schell (Eds.), Tage, die Deutschland und die Welt veränderten: Vom Mauerfall zum Kaukasus: Die deutsche Währungsunion (pp. 57-117). München: Edition Ferenczy bei Bruckmann.

Wegner, M. (1996). Die deutsche Einigung oder das Ausbleiben des Wunders. Aus Politik und Zeitgeschichte, 40, 13-23.

Zank, W. (1997). The power of legends and the long-term effects of short-term mistakes: The convulsion of monetary and economic transformation in East Germany 1990-1997. In T. Kowalski (Ed.), Financial reform in emerging market economies. Quantitative and institutional issues (pp. 261-285). Poznań: Wydawnictwo Akademii Ekonomicznej w Poznaniu.

Zank, W. (1998). The German Melting-Pot. Multiculturality in historical perspective. Houndmills, Basingstoke: Macmillan. 